November 2002 - NREL/TP-500-32471

\title{
The Effects of Net Metering on the Use of Small-Scale Wind Systems in the United States
}

T.L. Forsyth and M. Pedden

National Renewable Energy Laboratory

T. Gagliano

National Conference of State Legislatures

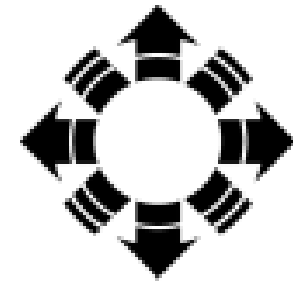

NPE1

National Renewable Energy Laboratory

1617 Cole Boulevard

Golden, Colorado 80401-3393

NREL is a U.S. Department of Energy Laboratory

Operated by Midwest Research Institute $\bullet$ Battelle $\bullet$ Bechtel

Contract No. DE-AC36-99-G010337 
November 2002 ・ NREL/TP-500-32471

\section{The Effects of Net Metering on the Use of Small-Scale Wind Systems in the United States}

T.L. Forsyth and M. Pedden

National Renewable Energy Laboratory

T. Gagliano

National Conference of State Legislatures

Prepared under Task No. WER2.4510

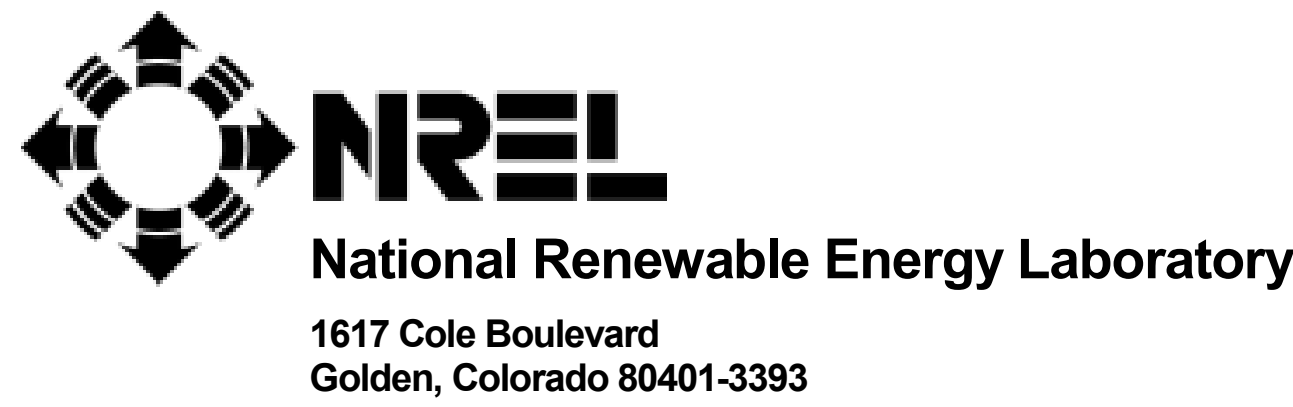

NREL is a U.S. Department of Energy Laboratory

Operated by Midwest Research Institute • Battelle • Bechtel

Contract No. DE-AC36-99-G010337 


\section{NOTICE}

This report was prepared as an account of work sponsored by an agency of the United States government. Neither the United States government nor any agency thereof, nor any of their employees, makes any warranty, express or implied, or assumes any legal liability or responsibility for the accuracy, completeness, or usefulness of any information, apparatus, product, or process disclosed, or represents that its use would not infringe privately owned rights. Reference herein to any specific commercial product, process, or service by trade name, trademark, manufacturer, or otherwise does not necessarily constitute or imply its endorsement, recommendation, or favoring by the United States government or any agency thereof. The views and opinions of authors expressed herein do not necessarily state or reflect those of the United States government or any agency thereof.

Available electronically at http://www.doe.gov/bridge

Available for a processing fee to U.S. Department of Energy

and its contractors, in paper, from:

U.S. Department of Energy

Office of Scientific and Technical Information

P.O. Box 62

Oak Ridge, TN 37831-0062

phone: 865.576 .8401

fax: 865.576.5728

email: reports@adonis.osti.gov

Available for sale to the public, in paper, from:

U.S. Department of Commerce

National Technical Information Service

5285 Port Royal Road

Springfield, VA 22161

phone: 800.553.6847

fax: 703.605.6900

email: orders@ntis.fedworld.gov

online ordering: http://www.ntis.gov/ordering.htm 


\section{Table of Contents}

Abstract foduction.




\section{List of Figures}

Figure 1. Current U.S. Residential Small Wind Incentives ............................................................2

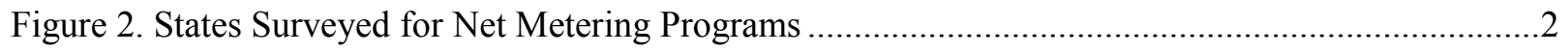

Figure 3. California Small Wind Turbine Installations....................................................................

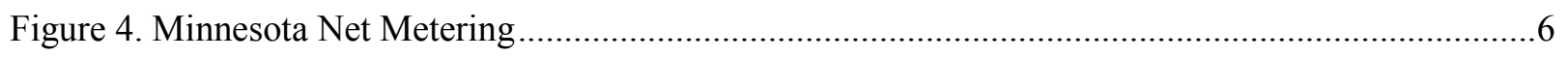

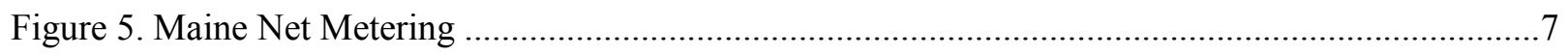

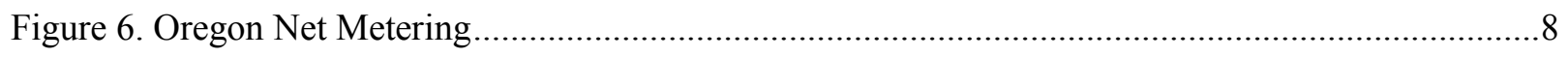

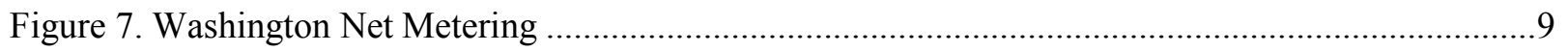

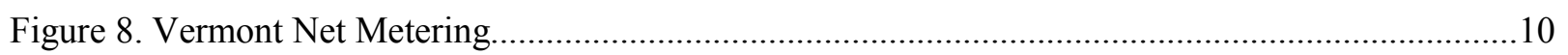

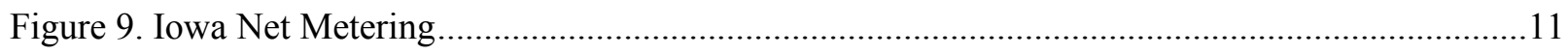

Figure 10. Total Installed Capacity of Net Metered, Small Wind Systems for 8 States (in kW) ............12 


\section{Abstract}

Factors such as technological advancements, steadily decreasing costs, consumer demand, and state and federal policies are combining to make wind energy the world's fastest growing energy source. State and federal policies are facilitating the growth of the domestic, large-scale wind power market; however, small-scale wind projects (those with a capacity of less than 100 kilowatts [kW]) still face challenges in many states. Net metering, also referred to as net billing, is one particular policy that states are implementing to encourage the use of small renewable energy systems. Net metering allows individual, grid-tied customers who generate electricity using a small renewable energy system to receive credit from their utility for any excess power they generate beyond what they consume. Under most state rules, residential, commercial, and industrial customers are eligible for net metering; however, some states restrict eligibility to particular customer classes.

This paper illustrates how net metering programs in certain states vary considerably in terms of how customers are credited for excess power they generate; the type and size of eligible technologies and whether the utility; the state, or some other entity administers the program. This paper focuses on 10 particular states where net metering policies are in place. It analyzes how the different versions of these programs affect the use of small-scale wind technologies and whether some versions are more favorable to this technology than others. The choice of citizens in some states to net meter with photovoltaics is also examined.

\section{Introduction}

Thirty-six states ${ }^{1}$ (figure 1) have adopted some form of net metering law for small wind and/or photovoltaic technologies. These laws were adopted either as legislative statutes or as rules formed by the state public utility commission. The 10 states analyzed here include California, Idaho, Illinois, Iowa, Maine, Minnesota, Nevada, Oregon, Vermont and Washington (figure 2). Appendix A provides a summary of the net metering programs in these states.

\footnotetext{
${ }^{1}$ New Mexico and Texas are included, although their net metering programs have been put on hold.
} 


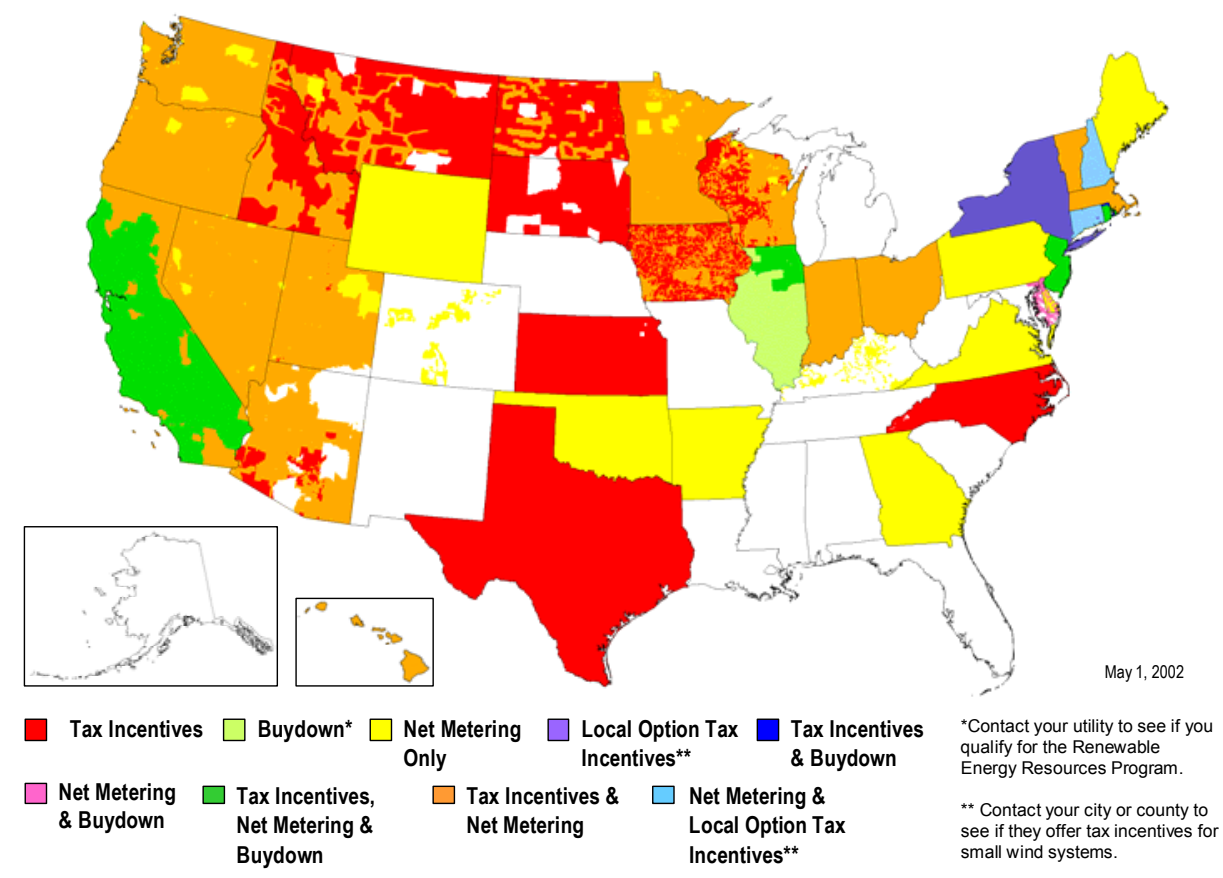

Figure 1. Current U.S. Residential Small Wind Incentives

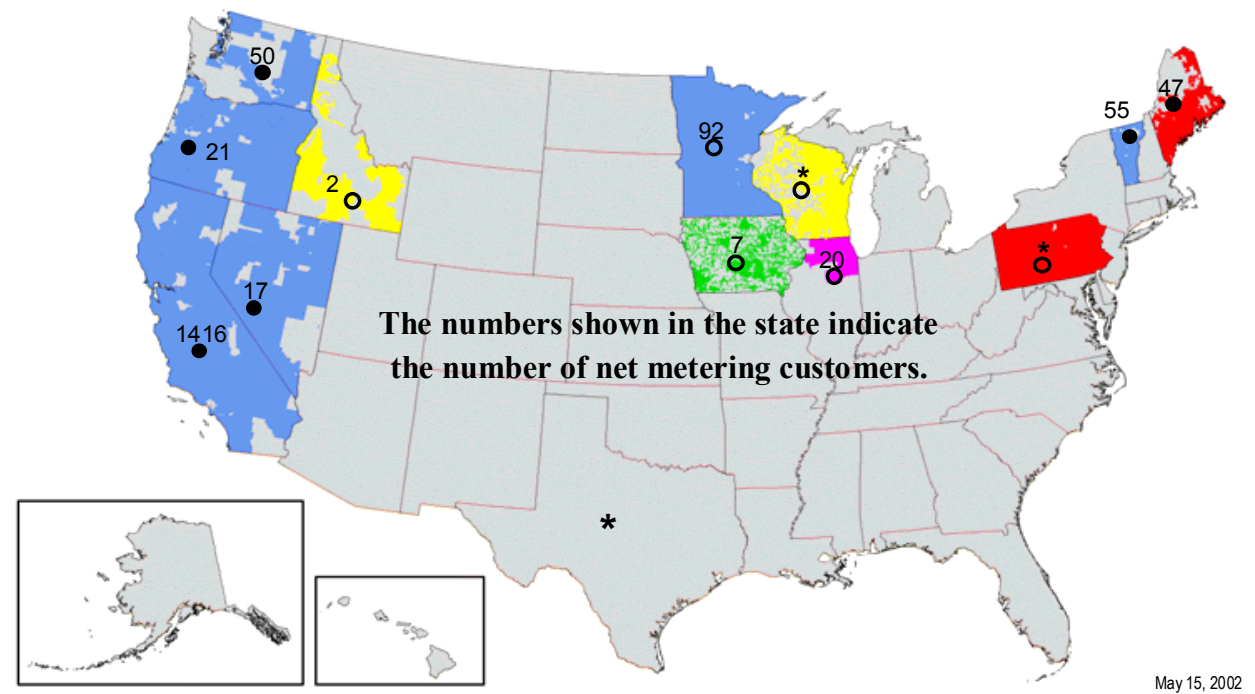

* Indicates attempt to gather number of net metering customers in the state, but inability

Net metering applies to IOUs \& $\square$ Net metering applies to RECs; Legislated

Net metering applies to IOUs;

PUC Regulated
IOUs \& RECs; PUC

Regulated

Net metering applies to

IOUs; Legislated
Net metering applies to

ComEd Territory only; not
regulated by PUC or regulated
legislated.

- Annual rollover of NEG

Figure 2. States Surveyed for Net Metering Programs 
Net metering programs and access to specific details about these programs vary considerably. It is difficult to compile data because many of the utilities that administer net metering programs consider information to be proprietary. Thus, the information collected for this analysis was greatly dependent upon the type of information the program administrator was willing or able to provide.

A major conclusion of this research is that net metering programs alone may not be sufficient to encourage customer participation. Combinations of net metering with either public education and outreach efforts or with other financial incentives - such as buy-down programs or low-interest loansmay encourage more customers to participate. Also, customers become more interested in net metering programs when they experience prolonged power outages. Enrollment in certain net metering programs increased in New England after ice storms in 1998 left people without power and in California after the rotating blackouts of 2001 .

\section{Methods}

States selected for this analysis were chosen based on criteria the authors thought might influence customer enrollment in net metering programs. These criteria included:

- The length of time that the program has been in operation;

- The number of participating utilities;

- The capacity limit placed on the size of the renewable energy system;

- The range of eligible customer classes;

- The limits placed on total customer enrollment either statewide or in a service area;

- The treatment of net excess generation; and

- The existence not only of net metering, but also of other incentives within the state.

To gather the necessary data, contacts in each state were identified and then interviewed via telephone or e-mail. This was accomplished to the greatest degree possible, but with varying results. As mentioned earlier, much information about net metering is considered proprietary and interview results were greatly dependent upon what the regulatory agency or utility was willing and able to provide.

\section{California}

California has the largest number of net-metered customers for any of the states that were researched in this paper. They have had the earliest adoption of state incentives, of which the buy-down program started in 1998. California is a unique state in that the rules governing environmental regulations and the opportunities for renewable energy tend to be quite progressive. This is due to the number of incentives in place that support renewable energy and energy efficiency, combined with general support for environmental awareness.

A total of 1,416 net metered systems have been approved and 994 net metered systems are pending approval in the territories of Southern California Edison (SCE), San Diego Gas \& Electric (SDG\&E), and Pacific Gas \& Electric (PG\&E), which account for all net metered customers. The large number of participating systems demonstrates the success of California's net metering program, which began in 1995. According to Scott Tomashefsky of the California Energy Commission (CEC), most of these installations are solar.

Gathering information about California's net metering programs proved to be somewhat difficult. Although the CEC and these three utilities collect the type of information requested (year projects put in 
place and technology being used), CEC, PG\&E, and SCE reported that it is confidential. SDG\&E was the only company willing to disseminate its net metering customer statistics on the type of technology being used and the year the system was put in place. PG\&E's web site provides useful information about its net metering program, including the net metering process, a checklist for completing interconnection agreement, the interconnection agreement and application, and net metering tariff. SDG\&E provides a packet of information upon request that includes details about its net metering and buy-down programs. The fact that this information is readily accessible and easy for consumers to understand may improve the chances of customer participation.

In searching for the information on the number of net metering customers using wind, we asked the CEC if it had this information. It did not, but it reported the total number of small turbines installed under its buy-down program (California financial incentive where the states pays 50 percent of the installed small turbine costs), as shown in figure 3. All these turbines installed under the buy-down also have net metering so we can determine that, at the minimum, $704 \mathrm{~kW}$ of wind net metering exists in California. The high number of net metering customers in California is due in part to the combination of financial incentives within the state. Clearly, there is an increase in the number of small turbine installations due to the combination of financial incentives, including the buy-down program, tax incentives, and net metering.

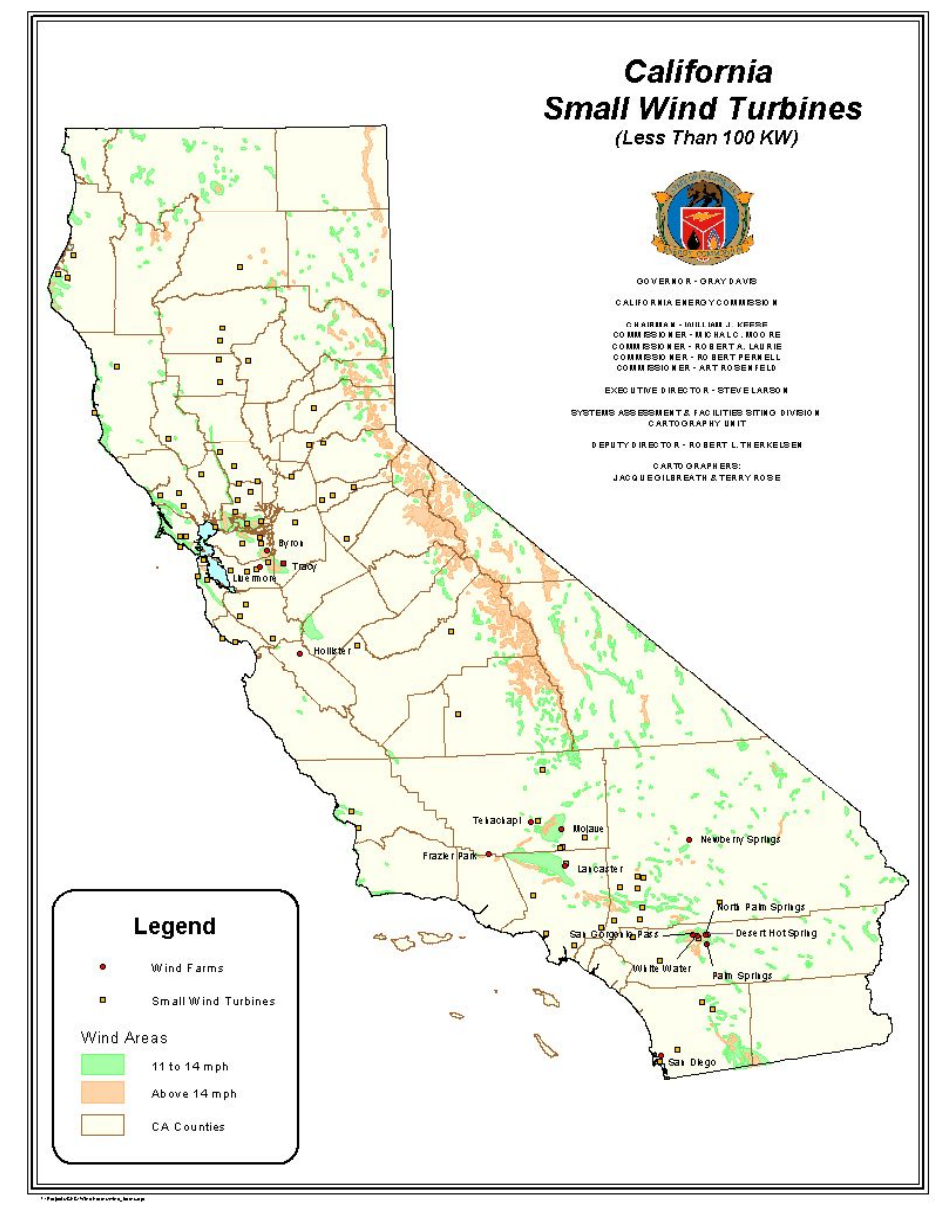

Figure 3. California Small Wind Turbine Installations 
David Ore with PG\&E, an interconnection hotline responder, reports that most of the small wind turbines in the PG\&E territories were installed mostly in rural areas. This may be due to residential zoning ordinances and "NIMBY" (not in my back yard) attitudes. Ore indicated that most of the existing systems in the PG\&E territory were installed in 2001. (There were only 170 net metering customers prior to January 2001.) This sudden increase can be partially attributed to increased electricity prices due to supply shortages in California during the summers of 2000 and 2001, as well as to the multiple financial incentives for home-based renewable energy systems.

Ore, who himself reviews up to seven new net metering applications each day, reports that this increase in enrollment for net metering is so great that both professional system installers and utility company employees who register new participants are overwhelmed.

Other factors that may have caused the recent interest in net metering in California include:

- The change in the net metering law to increase the system capacity limit to $1000 \mathrm{~kW}$;

- The buy-down program offered by the State of California (see http://www.consumerenergycenter.org/buydown/program.html); and

- The availability of information to the customer.

\section{Minnesota}

Minnesota's program began in 1983 with the net excess generation being purchased by the utility company at the average retail electricity rate. Currently, $232 \mathrm{~kW}$ of installed capacity is tied to wind net metering programs. Dan Juhl, a long-time wind advocate and wind businessman with DanMar \& Associates, suggests that Minnesota's net metering program began so early as a result of environmentally conscious citizens and because the state is short on domestic energy sources such as coal and natural gas. Currently, the number of small wind installations in Minnesota is decreasing, while the number of small solar installations is increasing. Juhl suggests that this may be because most of the customers who originally installed small wind systems for net metering were farmers and ranchers who installed systems of a relatively large $(>10 \mathrm{~kW})$ capacity for the time. Now these same farmers and ranchers are installing larger turbines, which are not part of the Minnesota net metering rules, which have a $40 \mathrm{~kW}$ capacity limit.

Another possible explanation for the decreasing interest in small wind turbines is the popularity of large utility-scale wind turbines. Farmers and ranchers across the Midwest have shown interest recently in leasing their land to wind developers that pay royalties based on the electrical output of the large turbines they construct. These turbines can generate significant revenue, but they are too large to qualify for net metering due to the $40 \mathrm{~kW}$ capacity size limit. Minnesota is a national leader, with production capacity of more than 320 megawatts (MW) from these large turbines.

Mike Taylor, with the Minnesota Department of Commerce, suggests additional reasons for the decrease in the number of small wind installations tied to net metering. According to Taylor, many of the small wind turbines installed in the late 1980s were composed of used wind equipment. Many of these turbines are being retired from use because the maintenance costs have become too high. Taylor also reports that it can be frustrating for customers to work with a utility to set up a net metering project when net metering is not high on the utility's list of priorities. In addition, Taylor reports that the height of wind turbines can put them in violation of local, county zoning restrictions in both residential and rural areas. (Typically, small turbines require a special use permit or other zoning permits for towers that are taller than 35 feet. This height limit is an artifact from the early 1900s when tall towers could not be accessed by fire fighting 
equipment.) Net metering customers who use photovoltaic systems in Minnesota do not appear to have such zoning problems.

Figure 4 illustrates how the number of net-metered wind projects has declined from nearly 110 to less than 70 between 1997 and 2001. During this same time, net-metered photovoltaic projects grew from fewer than five to more than 20. A possible explanation for the increased use of photovoltaic technology is the Northern States Power (NSP) Solar Loan Program that began in 1996. Also in 1997, the U.S. Department of Energy's Million Solar Roof initiative, an outreach and education initiative, was put in place. Both these initiatives may have contributed to the increase in solar installations in Minnesota.

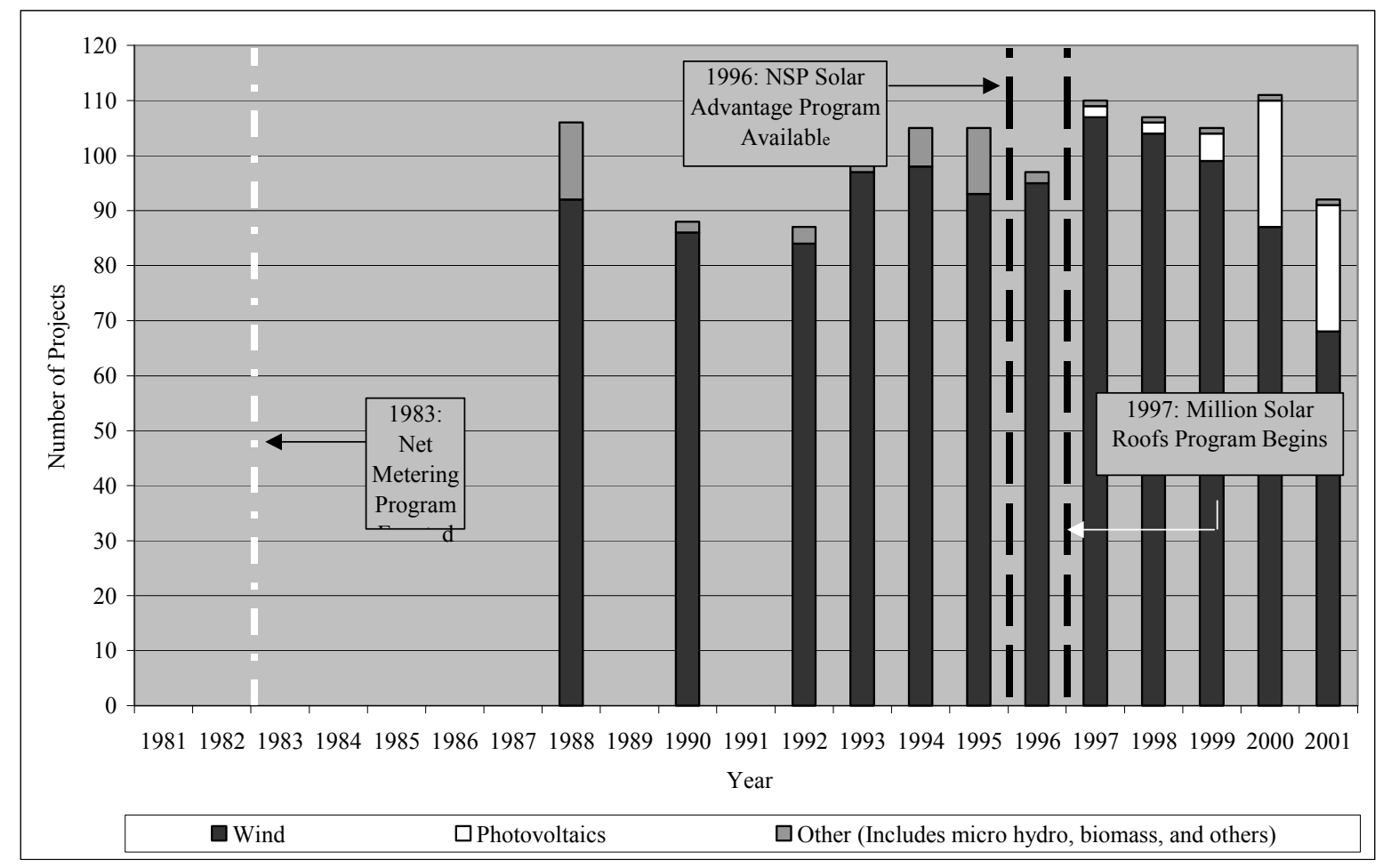

Figure 4. Minnesota Net Metering

\section{Maine}

The Public Utility Commission (PUC) in Maine administers the state's net billing program. According to Mitch Tannenbaum of the PUC, Central Maine Power and Bangor Hydro-Electric have customers participating in the program. Tannenbaum provided a general list of current net billing customers. Gary Cole, with Central Maine Power (CMP), provided a list of current and previous net billing customers, the date the customer started net billing, the type of technology in use, and the rated capacity of each project. CMP keeps detailed records of current contracts, any contracts that have expired, and the year of expiration. ${ }^{2}$ These data are shown in figure 5 , which illustrates changes in the number of net metering customers from 1981 to 2001.

\footnotetext{
${ }^{2}$ Maine and Minnesota are the only two states able to provide this kind of data, and it is most likely more accurate than the data collected from the other states.
} 


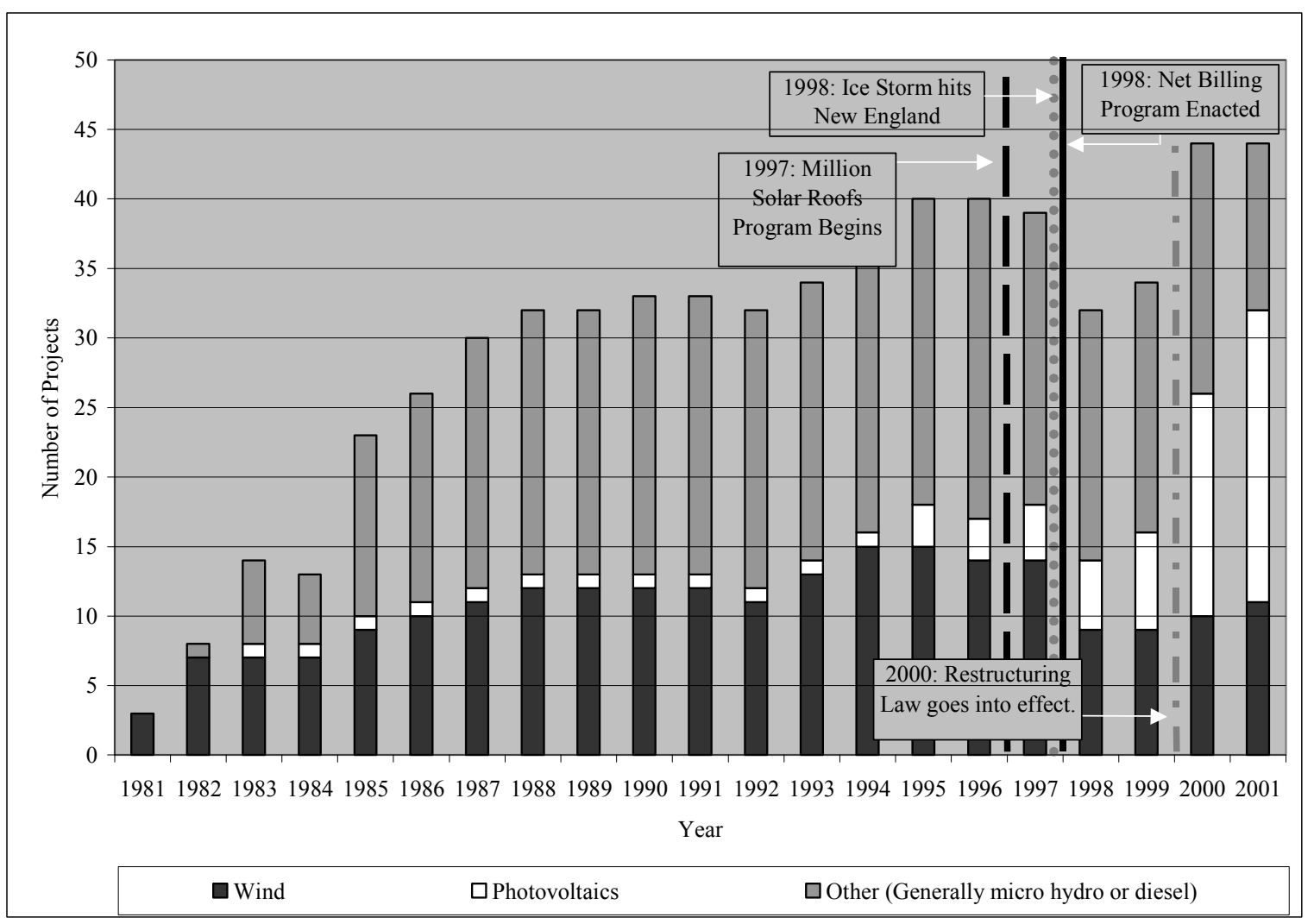

Figure 5. Maine Net Metering

Even before the passage of Maine's net billing program in 1998, CMP customers had the option to participate in a similar program started in 1981. This earlier version of net billing was less cumbersome for the customer than the present net billing program because the contract was less complicated, there was less liability for the customer, and there was no net billing expiration date. When the new net billing law was passed, CMP found it was difficult to switch customers from the old program because the new net billing contract was more complicated and included an expiration date.

According to Gary Cole, although the net billing program change was accomplished, some customersmostly those with small hydropower systems - no longer qualified under the new program because they were generating electricity to sell to CMP but were not using any of it themselves. The switch from CMP's earlier program to the current net billing program may have caused a drop in customer participation for two reasons. One is that some customers did not fit the requirements of the new net billing program; and the second is that some customers found the new net billing contract too cumbersome.

The complexity of the new net billing program could explain the drop in participation rates between 1997 and 1998. The slight increase in participation after 1998, however, could possibly be the result of increased customer interest in self-generation after a large ice storm took out power lines. (The same storm also affected Vermont). The power outages caused by the storm could have influenced many people to purchase small wind or solar systems to use as a backup power source. 


\section{Oregon}

Although no small wind systems are currently net-metered in Oregon, the state is included here to further illustrate how customers' concerns about the reliability of the electric system can influence their participation in net metering programs. Figure 6 shows Oregon net metering, which has 20 solar installations and one micro hydropower installation. Interestingly, the data shows a dramatic upward trend in the number of solar installations, growing from just three installations in 1999 to 20 in 2001 . One possible explanation for this is that customers in Oregon who were affected by the power shortage in California wish to generate their own power to protect themselves from future power shortages.

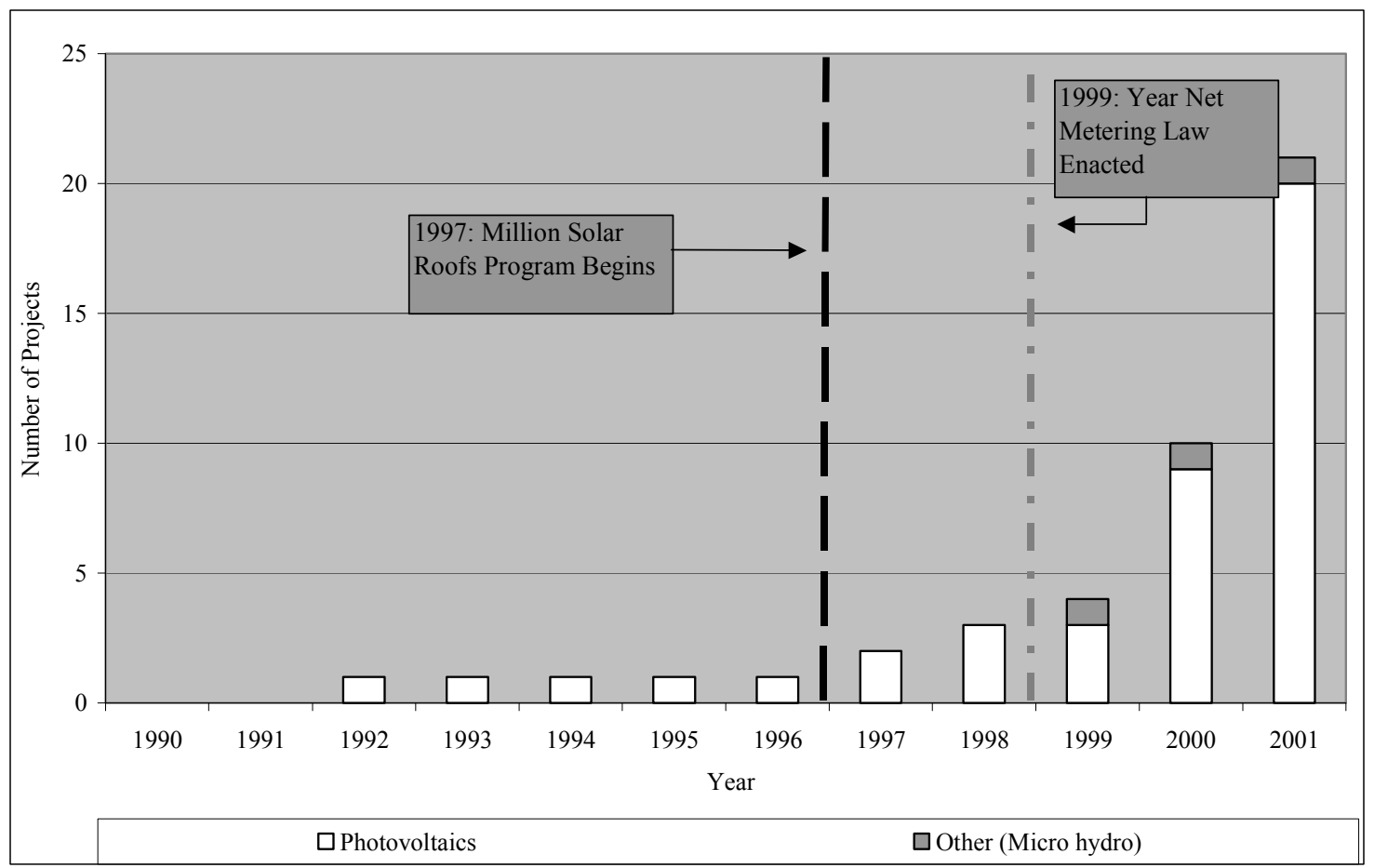

Figure 6. Oregon Net Metering

Lani Pennington, of the PGE Tariff Administration with Portland General Electric (PGE), suggests that the lack of small wind installations in Oregon may be due to the weak wind resource in the Willamette Valley, where the majority of net metering customers are located. Bruce Barney, PGE's net metering coordinator, says he typically receives about two calls per week from people who are interested in net metering. Barney says that approximately one out of 10 people call again after receiving an information packet. He contributes this low ratio of callbacks to the cost of renewable energy systems. He agrees with Pennington that the generally poor wind resource in Oregon and the cost of capital investment in renewable energy systems may affect customers' decisions to invest in a small wind system.

\section{Washington}

Poor wind resources in much of Washington may explain the small number of net-metered wind installations there. Mike Nelson is with Western Sun Cooperative, a photovoltaics system purchasing cooperative. He estimates that about 10 percent of the land in Washington is suitable for small wind systems and believes that the lack of qualified turbine installers may be the reason for the low number of small wind net metered projects. Compared to small wind systems, photovoltaic systems are 
comparatively easy to install, and many licensed electricians are capable of installing photovoltaic systems. The ease of installation may be one reason for the disparity between the number of installed photovoltaic systems and wind systems (figure 7).

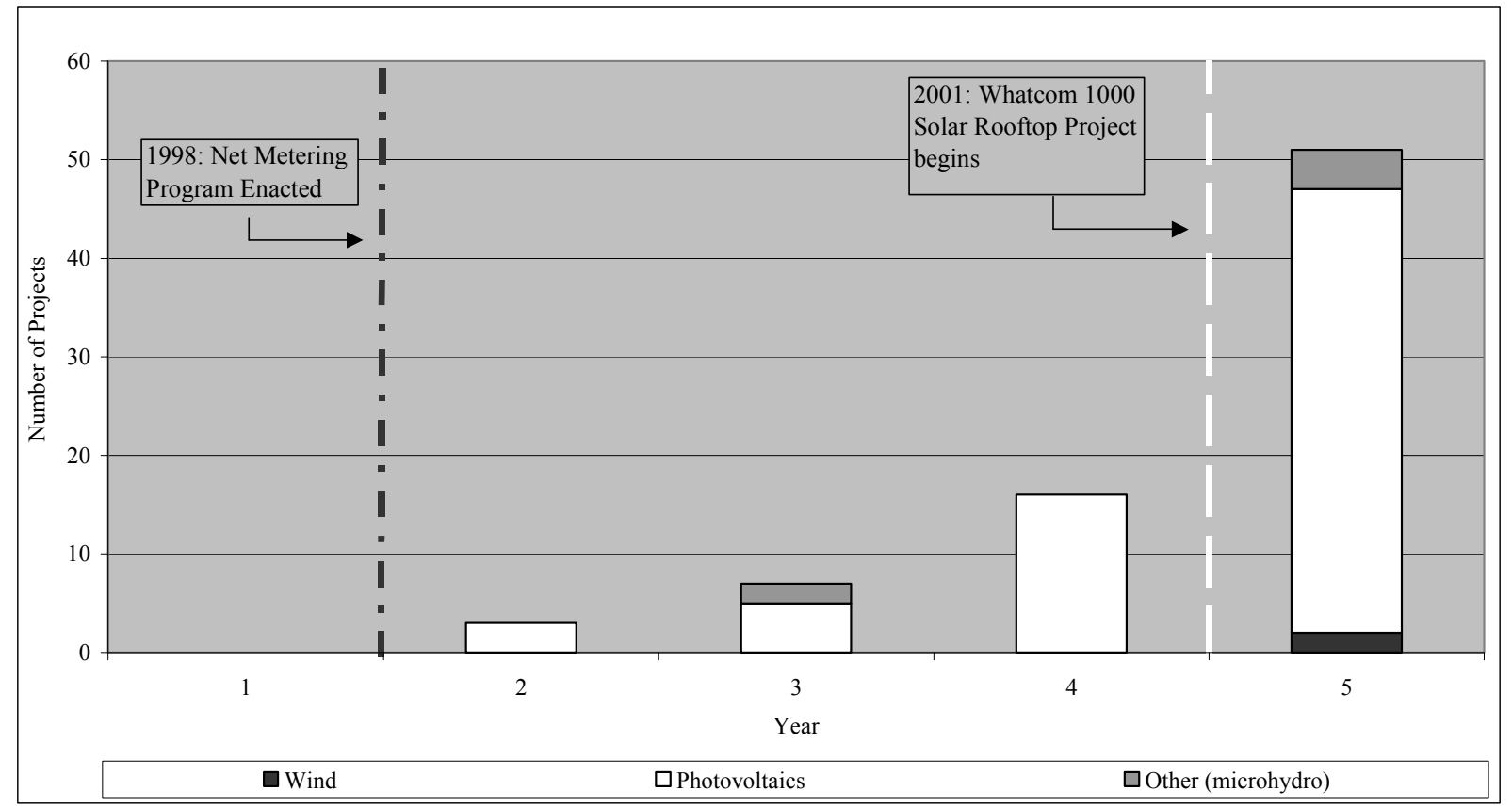

Figure 7. Washington Net Metering

The number of photovoltaic installations in Washington increased from 16 in 2000 to 45 in 2001. Part of this increase may be contributed to the Whatcom 1000 Solar Rooftop Project, initiated in January 2001. The mission of this project is to shift the community's perception about using renewable power generation systems via education and outreach and to help site, finance, and install 1,000 solar rooftop projects by December 31, 2010. Participants must have existing utility service, the existing electrical system must pass inspection, and participants must be willing to sign the net metering agreement with Puget Sound Energy.

It is possible that the advocacy portion of the project has affected solar installations outside Whatcom and Skagit counties by creating an overall awareness of renewable energy in Washington. Orcas Power and Light Cooperative (OPALCO), the utility that serves several groups of islands off the northwest coast of Washington, also has experienced a recent increase in the number of installations. This increase may be due to island residents' concerns about reliability of service.

\section{Vermont}

Although the number of solar and wind system installations are increasing in Vermont (figure 8), interest in net metering remains comparatively low. There are two possible explanations for this. First, because the program is fairly new, many customers may not yet know of its existence. Second, the permitting process for small wind turbines can be cumbersome and expensive. David Grover, with the Vermont Department of Public Service (DPS), believes that the current lack of participation in net metering can be accredited to the fact that it is a new program. He also believes that an abundance of cheap oil and misconceptions about renewable energy also may explain why net metering has not been more successful in Vermont. 


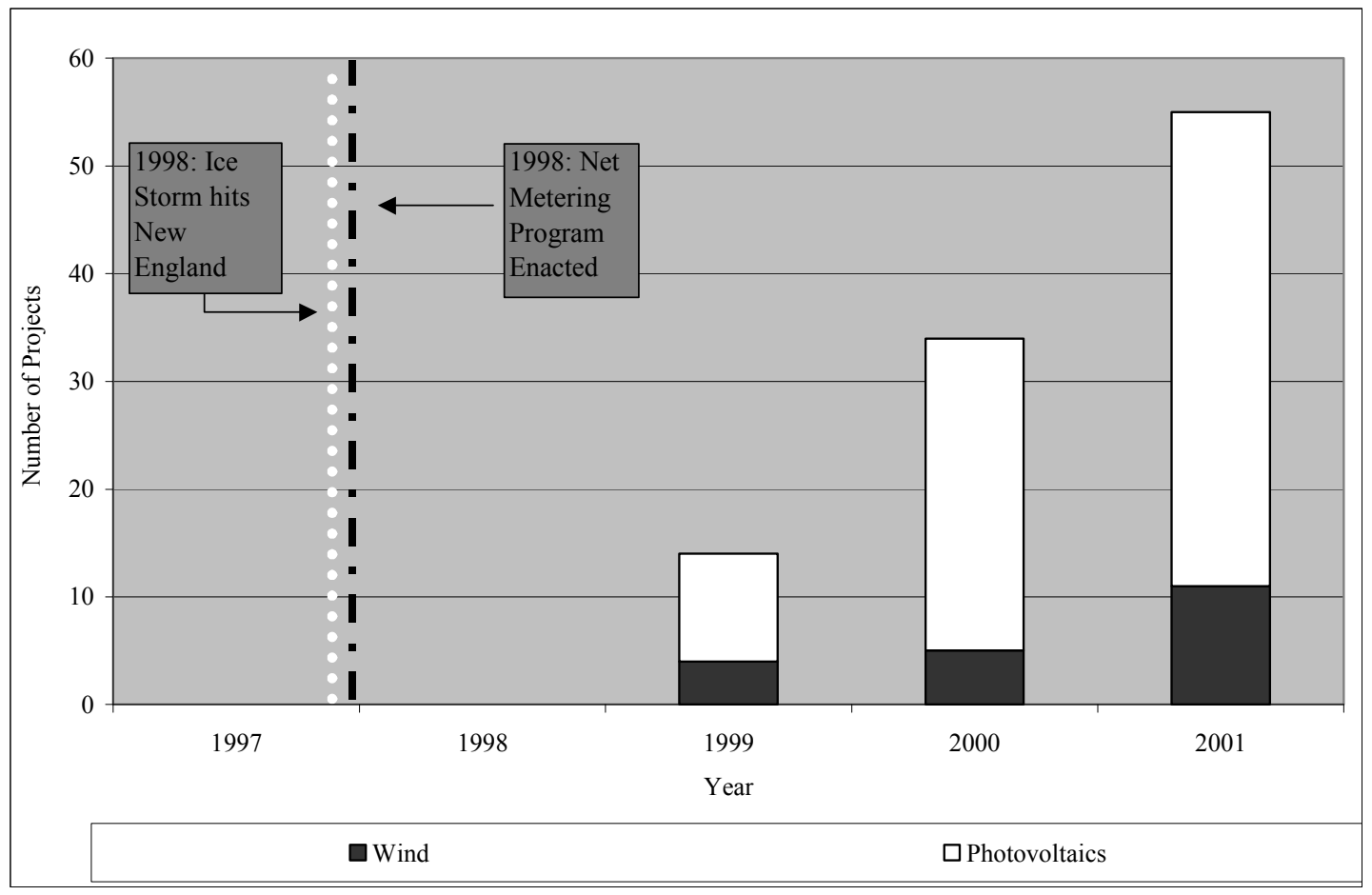

Figure 8. Vermont Net Metering

The experience of Dave Blittersdorf, a small turbine owner in Vermont, illustrates how wind turbines can be subject to greater scrutiny than photovoltaic systems. Customers in Vermont who wish to participate in net metering must obtain a Certificate of Public Good (CPG) from the Public Service Board. This is the same permit required for siting a large, commercial power plant in the state, but solar installations are not required to get a CPG. According to Blittersdorf, the most difficult part of the permitting process (part of getting a CPG) for small wind turbines is the aesthetics review, a process that is not required for rooftop photovoltaic systems. Also, as part of the permitting process, neighbors are allowed to contest an installation. Blittersdorf's system was the first to be contested on the grounds of noise and visual impact. Blittersdorf hired a lawyer and, after 11 months, secured his certificate. He estimates that this permitting process cost Vermonters about $\$ 10,000$ for the time the Department of Public Service spent on his case. In addition, he estimates his costs for time and legal expenses at nearly $\$ 9,500$.

\section{Highlights}

In addition to the net metering programs investigated above, the net metering programs in, Idaho, Illinois, Iowa, Nevada and Texas were explored. However, information for these states was scarce.

- Idaho: According to the Idaho PUC, customers have expressed interest in an expanded net metering law that would include all customers of Idaho Power. At the request of the Idaho PUC, Idaho Power recently filed a revised net metering tariff to decrease the original capacity limit of $100 \mathrm{~kW}$ to $25 \mathrm{~kW}$ for residential and small commercial customers, and to add all other customer classes, such as irrigation customers and dairy farmers. This tariff is still undergoing review and has not yet been passed. Currently, Idaho has only three net metering customers.

- Illinois: According to Denise Bechen, a manager with Commonwealth Edison, the utility offered a net metering program called The Wind and Photovoltaic Generation Pricing Experiment. This 
five-year program allows customers to reduce their energy costs by net metering in addition to receiving an annual payment from the utility, depending on how much energy the system produces. Currently, the program has 20 participants, representing $57.06 \mathrm{~kW}$ of wind and solar generation as of December 31, 2001.

- Iowa: Only partial information on the number of customers participating in a net metering program was available (those from Alliant Energy; see figure 9). However, the chronicle of net metering in Iowa is interesting because MidAmerican, an Iowa utility, recently challenged the net metering law passed by the Iowa legislature in 1983, claiming it to be unconstitutional and in conflict with the Federal PURPA law. Settlement of this dispute resulted in the change of the capacity limit to $500 \mathrm{~kW}$, applicable only to customers of MidAmerican. Due to this conflict with the Iowa Utilities Board, MidAmerican has not offered net metering to its customers since 1999, but net metering will be reinstated with the new tariff in late 2002 .

- Nevada: Mark Harris, a resource planning engineer with the Nevada PUC, suggests that net metering became more popular in Nevada when the price for electricity began to increase; prices currently are at about 10 cents per kilowatt-hour. At the end of calendar year 2001, there were a total of $43.0 \mathrm{~kW}$ of installed wind and photovoltaics. All the net-metered systems had a photovoltaic component and, three of the systems had wind/photovoltaic hybrids.

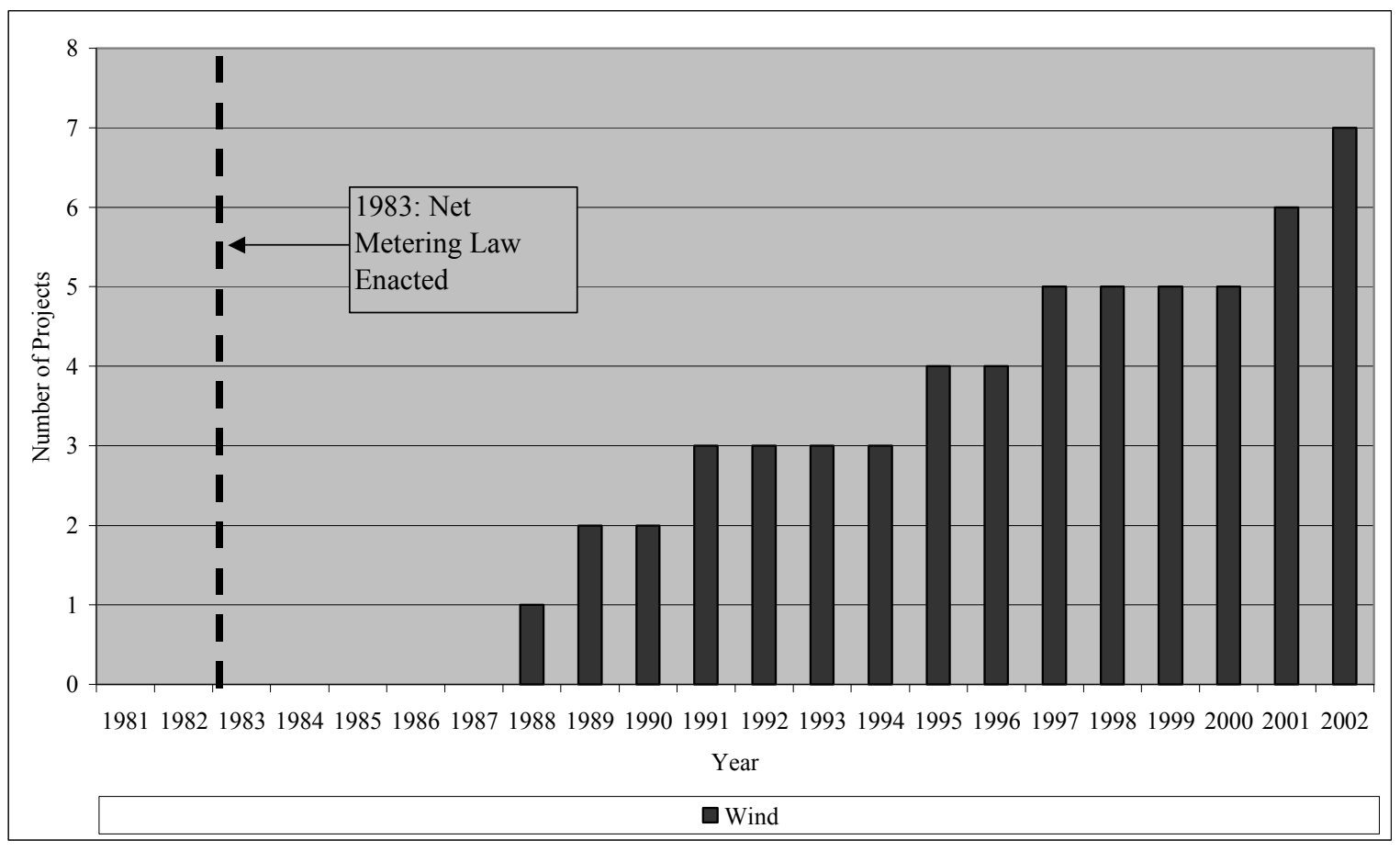

Figure 9. lowa Net Metering

- Texas: According to Russel Smith, executive director of Texas Renewable Energy Industries Association (TREIA), the Texas net metering program is no longer applicable because of restructuring. Some utilities claim that, because the section of the PUC rules applying to net metering was not changed, it does not apply to a regulated system. Investor-owned utilities have been broken up into generation companies, transmission and distribution companies, and retail 
electric providers and no longer are regulated by the PUC rules that existed before restructuring. Thus, it is arguable that the rule no longer applies. TREIA is hoping to change the net metering law through PUC channels by the end of this year to make it applicable. Some utilities-

including Austin Electric, San Antonio's City Public Service, and Kerrville Electric - continue to honor previous net metering agreements and allow new net metering customers.

\section{Conclusion}

For eight of the states surveyed, a total of $1,363 \mathrm{~kW}$ of installed small grid-connected wind existed at the end of 2001 as shown in figure 10.

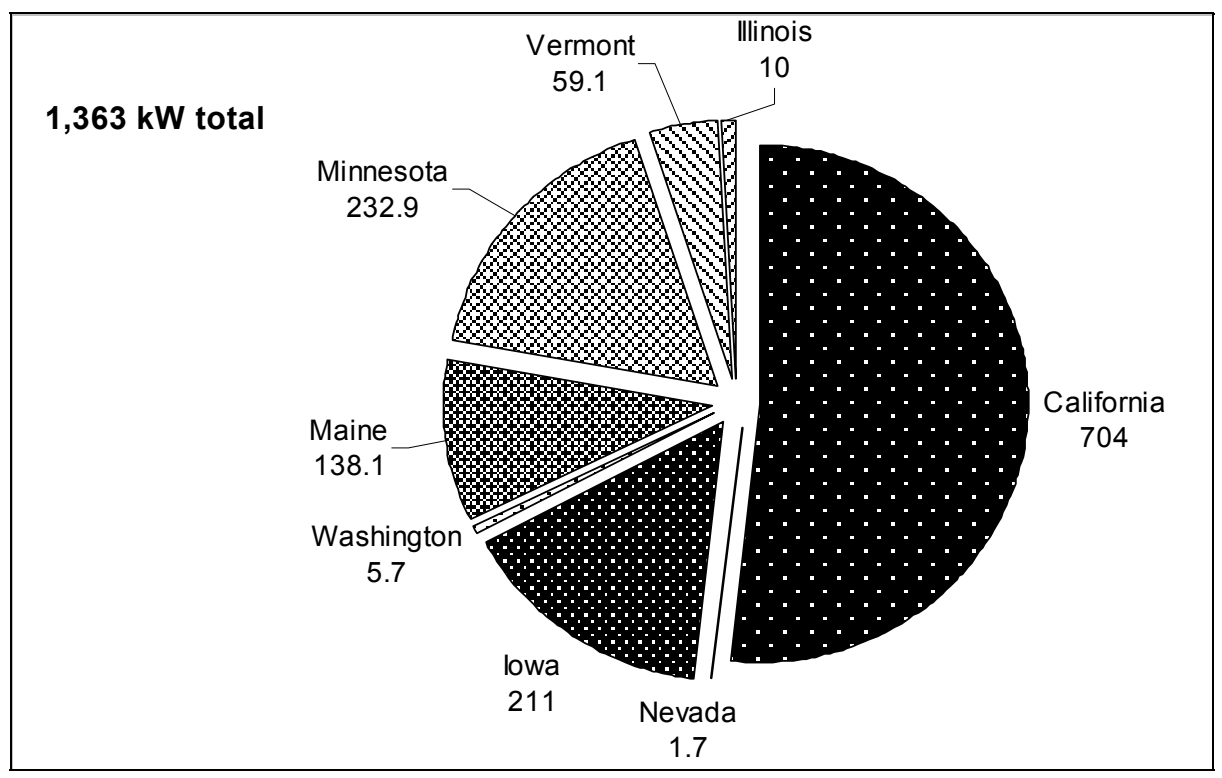

Figure 10. Total Installed Capacity of Net Metered, Small Wind Systems for 8 States (in kW)

Although it is difficult to show specific cause and effect for the data presented, some conclusions can be drawn. The first is that net metering programs alone seem to offer minimal incentive for consumers, particularly in light of difficulties with county zoning officials and cumbersome interconnection agreements.

Another conclusion is that when consumers are concerned about utility service reliability issues due to storms (like the New England ice storm in 1998), brown outs (like those experienced in California in the summer of 2001), or higher electricity rates, there is an increase in net metering customers. This is particularly true for states and counties where helpful financial incentives exist for home-based renewable energy projects.

It also appears that when there are multiple incentives for net-metered systems in addition to education and outreach programs (such as the Million Solar Roofs Program), the number of net-metered installations increases. This suggests that education and outreach programs can influence the number of net-metered customers.

In general, fear - more than economics - may motivate consumers to seek out and utilize home-based renewable energy systems. 


\section{Acknowledgements}

Special thanks go to all the people listed below who helped us understand net metering at a state, utility, or consumer level.

Bruce Barney (Portland General Electric)

Valerie Beck (California PUC)

David Blittersdorf (Vermont homeowner)

Denise Bechen (Illinois Commonwealth Edison)

Stephenie Carlyle (Sierra Pacific Power)

Ralph Chapman (Endless Energy)

Gary Cole (Central Maine Power)

John Dunlop (AWEA Northern Plains Regional Manager)

Graciela Etchart (Washington Utilities and Transportation Commission)

David Grover (Vermont Department of Public Service)

Bill Griffith (PacifiCorp)

Gene Fadness (Idaho PUC)

Tom Halnon (Vermont homeowner)

Mark Harris (Nevada PUC)

Dan Juhl (Dan Mar and Associates)

Robert Keithly (San Diego Gas \& Electric)

Bill McNamee (Oregon PUC)

Scott Mitchell (Nevada Power Company)

Mike Nelson (Western Sun Cooperative)

David Ore (Pacific Gas and Electric)

Lani Pennington (Portland General Electric)

Russel Smith (Texas Renewable Energy Industries Association)

Mitch Tannenbaum (Maine PUC)

Mike Taylor (Minnesota Department of Commerce)

Scott Tomashefsky (California Energy Commission)

Dora Yen (California Energy Commission) 


\section{Appendix A. Net Metering Program Summary}

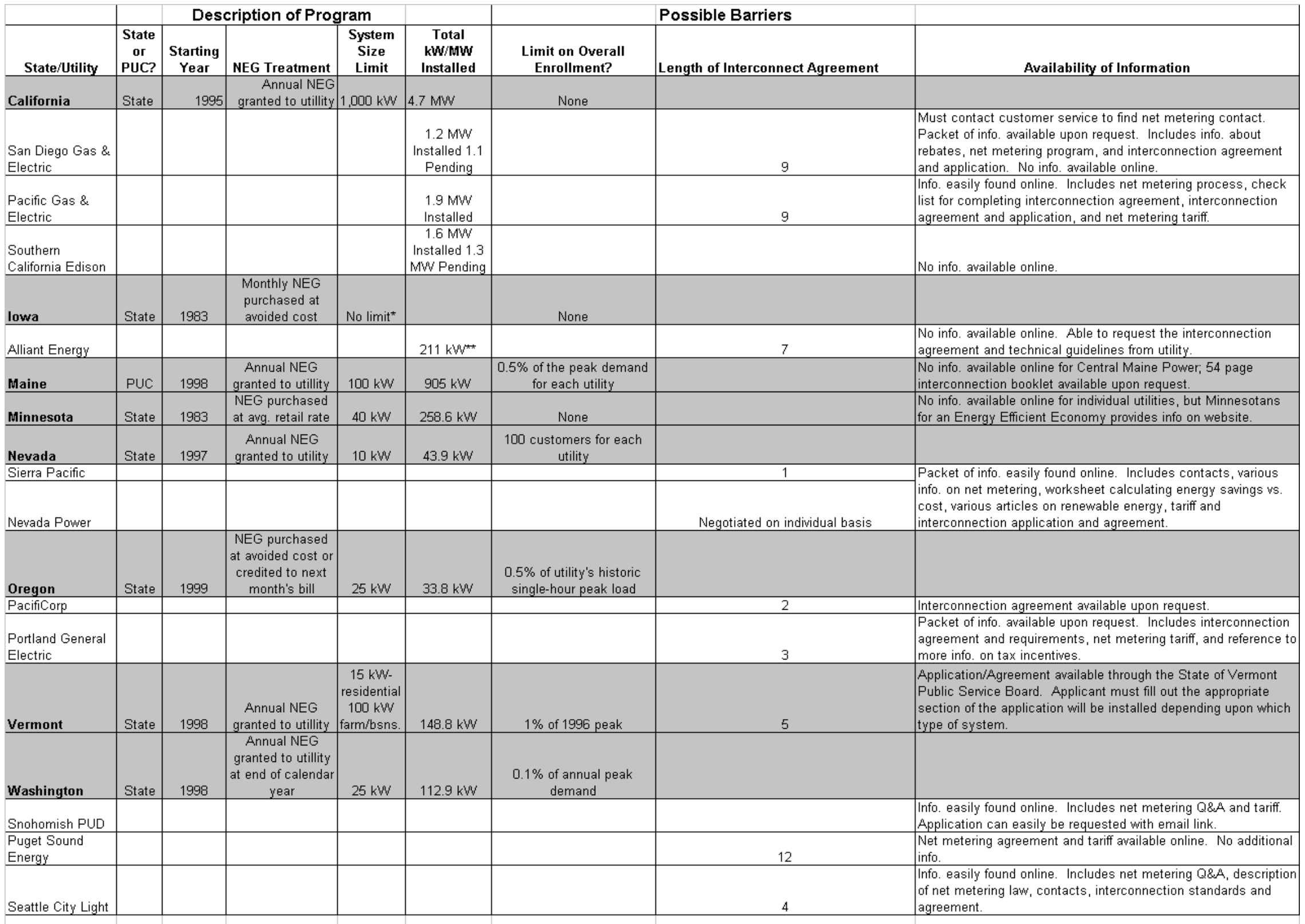

* All of lowa has no limit except for MidAmerican, which recently passed a $500 \mathrm{~kW}$ limit.

* Alliant Energy has some net metering customers with systems larger than $100 \mathrm{KW}$. Only the rated capacity from systems under $100 \mathrm{~kW}$ are included.

Note: Information for Illinois Commonwealth Edison and Idaho is not included. 


\section{REPORT DOCUMENTATION PAGE}

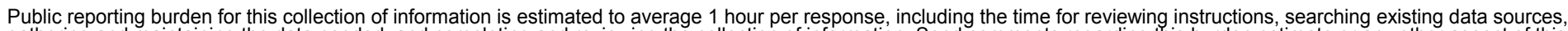

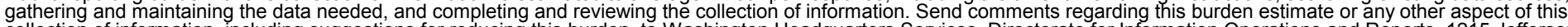
to Washington Headquarters Services, Directorat Davis Highway, Suite 1204, Arlington, VA 22202-4302, and to the Office of Management and Budget, Paperwork Reduction Project (0704-0188), Washington, DC 20503.
1. AGENCY USE ONLY (Leave blank)
2. REPORT DATE
November 2002
3. REPORT TYPE AND DATES COVERED
Technical Paper

\section{TITLE AND SUBTITLE}

The Effects of Net Metering on the Use of Small-Scale Wind Systems in the United States
5. FUNDING NUMBERS

WER2.4510

\section{6. $\operatorname{AUTHOR}(\mathrm{S})$}

T. Forsyth, M. Pedden, and T. Gagliano

7. PERFORMING ORGANIZATION NAME(S) AND ADDRESS(ES)

8. PERFORMING ORGANIZATION REPORT NUMBER

9. SPONSORING/MONITORING AGENCY NAME(S) AND ADDRESS(ES)

National Renewable Energy Laboratory

1617 Cole Blvd.

Golden, CO 80401-3393

10. SPONSORING/MONITORING AGENCY REPORT NUMBER

NREL/TP-500-32471

11. SUPPLEMENTARY NOTES

12a. DISTRIBUTION/AVAILABILITY STATEMENT

National Technical Information Service

12b. DISTRIBUTION CODE

U.S. Department of Commerce

5285 Port Royal Road

Springfield, VA 22161

13. ABSTRACT (Maximum 200 words)

Factors such as technological advancements, steadily decreasing costs, consumer demand, and state and federal policies are combining to make wind energy the world's fastest growing energy source. State and federal policies are facilitating the growth of the domestic, large-scale wind power market; however, small-scale wind projects (those with a capacity of less than 100 kilowatts [kW]) still face challenges in many states. Net metering, also referred to as net billing, is one particular policy that states are implementing to encourage the use of small renewable energy systems. Net metering allows individual, gridtied customers who generate electricity using a small renewable energy system to receive credit from their utility for any excess power they generate beyond what they consume. Under most state rules, residential, commercial, and industrial customers are eligible for net metering; however, some states restrict eligibility to particular customer classes.

This paper illustrates how net metering programs in certain states vary considerably in terms of how customers are credited for excess power they generate; the type and size of eligible technologies and whether the utility; the state, or some other entity administers the program. This paper focuses on 10 particular states where net metering policies are in place. It analyzes how the different versions of these programs affect the use of small-scale wind technologies and whether some versions are more favorable to this technology than others. The choice of citizens in some states to net meter with photovoltaics is also examined.

14. SUBJECT TERMS

Net metering; small-scale wind systems
15. NUMBER OF PAGES

16. PRICE CODE

20. LIMITATION OF ABSTRACT OF THIS PAGE Unclassified
19. SECURITY CLASSIFICATION OF ABSTRACT Unclassified
UL 